\title{
$\beta$-NGF Stimulates Steroidogenic Enzyme and VEGFA Gene Expression, and Progesterone Secretion via ERK 1/2 Pathway in Primary Culture of Llama Granulosa Cells
}

OPEN ACCESS

Edited by:

Regiane R. Santos,

Schothorst Feed

Research, Netherlands

Reviewed by: Paulo Bayard Dias Goncalves, Federal University of Pampa, Brazil

Fabio S. Lima

University of California, Davis,

United States

*Correspondence: Marcelo Hector Ratto marceloratto@uach.c

Specialty section: This article was submitted to

Animal Reproduction -

Theriogenology,

a section of the journal

Frontiers in Veterinary Science

Received: 22 July 2020 Accepted: 07 September 2020

Published: 23 October 2020

Citation:

Valderrama X, Ulloa-Leal C, Silva ME,

Goicochea J, Apichela S, Argañaraz M, Sari L, Paiva L, Ratto VF and Ratto MH (2020) $\beta$-NGF

Stimulates Steroidogenic Enzyme and

VEGFA Gene Expression, and Progesterone Secretion via ERK 1/2 Pathway in Primary Culture of Llama Granulosa Cells.

Front. Vet. Sci. 7:586265 doi: 10.3389/fvets.2020.586265

\begin{abstract}
Ximena Valderrama ${ }^{1}$, Cesar Ulloa-Leal ${ }^{2}$, Mauricio Erciario Silva ${ }^{3}$, Jose Goicochea ${ }^{4}$, Silvana Apichela ${ }^{5}$, Martin Argañaraz ${ }^{5}$, Luciana Sari ${ }^{5}$, Luis Paiva ${ }^{2}$, Vicente Francisco Ratto $^{2}$ and Marcelo Hector Ratto ${ }^{2 *}$

${ }^{1}$ Instituto de Investigaciones Agropecuarias (INIA), Osorno, Chile, ${ }^{2}$ Institute of Animal Science, Faculty of Veterinary Sciences, Universidad Austral de Chile, Valdivia, Chile, ${ }^{3}$ Department of Veterinary Sciences and Public Health, Faculty of Natural Resources, Universidad Catolica de Temuco, Temuco, Chile, ${ }^{4}$ Department of Surgery and Reproductive Biotechnology, Faculty of Veterinary Medicine and Zootechnics, Universidad Nacional Hermilio Valdizán, Huánuco, Peru, ${ }^{5}$ Instituto Superior de Investigaciones Biológicas (INSIBIO), CONICET-UNT, Facultad de Bioquímica, Instituto de Biología "Dr. Francisco D. Barbieri," Química y Farmacia, UNT, San Miguel de Tucumán, Argentina
\end{abstract}

The beta-nerve growth factor ( $\beta$-NGF) from llama seminal plasma exerts ovulatory and luteotrophic effects following intramuscular or intrauterine infusion in llamas and alpacas. In this study, we investigate the in vitro effect of llama $\beta$-NGF on the expression of genes involved in angiogenesis and progesterone synthesis as well as progesterone release in preovulatory llama granulosa cells; we also determine whether these changes are mediated via the ERK1/2 signaling pathway. From adult female llamas, we collected granulosa cells from preovulatory follicles by transvaginal ultrasound-guided follicle aspiration; these cells were pooled and incubated. After 80\% confluence, the cultured granulosa cells were treated with $\beta$-NGF, $\beta$-NGF plus the MAPK inhibitor U0126, or luteinizing hormone, and the abundance of angiogenic and steroidogenic enzyme mRNA transcripts were quantified after 10 and $20 \mathrm{~h}$ by RT-qPCR. We also quantified the progesterone concentration in the media after $48 \mathrm{~h}$ by radioimmunoassay. We found that application of $\beta$-NGF increases the abundance of mRNA transcripts of the vascular endothelial growth factor (VEGFA) and the steroidogenic enzymes cytochrome P450 side-chain cleavage (P450scc/CYP11A1), steroidogenic acute regulatory protein (STAR), and 33-hydroxysteroid dehydrogenase (HSD3B1) at 10 and $20 \mathrm{~h}$ of treatment. Application of the MAPK inhibitor U0126 resulted in downregulation of the genes encoding these enzymes. $\beta$-NGF also enhanced progesterone synthesis, which was prevented by the prior application of the MAPK inhibitor U0126. Finally, western blot analysis confirmed that $\beta$-NGF activates the ERK $1 / 2$ signaling pathway. In conclusion, our results indicate that $\beta$-NGF exerts direct luteotropic effects on llama ovarian tissue via the ERK $1 / 2$ pathway.

Keywords: HSD3B1, CYP11A1, CYP19A1, MAPK, U0126, corpus luteum, follicle, STAR 


\section{INTRODUCTION}

It is now well-established that the beta-nerve growth factor ( $\beta$ NGF) present in the seminal plasma of llamas and alpacas is the essential signal inducing the luteinizing hormone (LH) surge and ovulation in these species (1). Purified llama $\beta$-NGF also has a significant luteotrophic effect after intramuscular or intrauterine infusion in llamas and alpacas $(2,3)$. It is reported that plasma progesterone (since day 8 from ovulation) and corpus luteum (CL) diameter at day 16 are greater in llamas given two doses of $1 \mathrm{mg}$ of purified $\beta$-NGF than those given a single dose (4). The increase of the vascular area of the CL is positively correlated to progesterone production in llamas treated with $\beta$-NGF $(4,5)$. Interestingly, administration of $\beta$-NGF is also shown to improve luteal function in cows (6).

In llamas, the preovulatory $\mathrm{LH}$ surge induced by purified llama $\beta$-NGF is more sustained than that the observed after $\mathrm{GnRH}$ administration $(7,8)$, suggesting that the luteotrophic effect of $\beta$-NGF could be due to this prolonged LH secretion profile. In this sense, systemic administration of $\beta$-NGF increased CL vascularization and upregulated the expression of cytochrome P450 side-chain cleavage (P450scc encoded by CYP11A1) and steroidogenic acute regulatory protein (STAR) mRNA transcripts enhancing plasma progesterone concentrations during the early luteal phase in llamas (9). Also, systemic administration of purified llama $\beta$-NGF induced a rapid shift from estradiol to progesterone synthesis in the preovulatory follicle in llamas as evidenced by the in vivo increase of the progesterone/estradiol ratio in the follicular fluid and upregulation of genes related to progesterone production (10).

The presence of NGF and its high-affinity receptor trkA in granulosa, theca, and luteal cells of mammalian species (11-13) suggests that the luteotrophic effect of $\beta$-NGF may be exerted not only by the prolonged LH secretion pattern, but also directly by acting at the ovarian level. In a recent study, the addition of purified llama $\beta$-NGF upregulated the expression of STAR and vascular endothelial growth factor (VEGFA) transcripts in primary culture of llama granulosa cells (10).

Previous studies investigating the effect of NGF/trkA on steroidogenesis in the ovary have been conducted in granulosa or theca cells from cows (14) and humans (15), species classified as spontaneous ovulators, and so might not be the same than those of llamas. After copulation, female llamas have been shown to increase their plasmatic content of $\beta$-NGF concomitantly occurring with the $\mathrm{LH}$ discharge from the posterior pituitary (16), which hampers the discrimination of $\beta$-NGF and LH effects on follicle cells in vivo. The use of an in vitro system may serve to elucidate the potential local effects of these hormones on luteal function, and thus, the effects of $\beta$-NGF are not confounded by those of the endogenous LH release.

In this study, we investigate the effect of $\beta$-NGF on steroidogenic enzymes and VEGFA gene expression as well as progesterone secretion and test whether these effects are mediated via ERK1/2 signaling pathway in vitro using a primary culture of granulosa cells collected from llama preovulatory follicles.

\section{MATERIALS AND METHODS}

\section{Animals}

Llamas were kept at the llama research farm of the Institute of Animal Science, Universidad Austral de Chile, Valdivia, Chile $\left(39^{\circ} 38^{\circ} \mathrm{S}-73^{\circ} 5^{\circ} \mathrm{W}\right.$ and $19 \mathrm{~m}$ above sea level) and were maintained in pens and had access to natural pasture supplemented with hay and water ad libitum.

Experimental procedures were reviewed and approved by the University Bioethical Committee and were performed in accordance with the Chilean Animal Protection Act (2009) and the university animal care protocols.

\section{Semen Collection and Protein Purification}

Semen was collected from five mature male llamas, twice per week for 5 months before the start of the experiments. An artificial sheep vagina was used as previously described (2). Each ejaculate was diluted 1:1 ( $\mathrm{vol} / \mathrm{vol})$ with phosphate-buffered saline (PBS; Gibco, Grand Island, NY, USA) and centrifuged for $30 \mathrm{~min}$ at $1,500 \times \mathrm{g}$ at room temperature. A pool of spermfree seminal plasma was stored at $-20^{\circ} \mathrm{C}$. Purification of $\beta$-NGF was performed in a two-step procedure as previously described $(17,18)$. In brief, seminal plasma was loaded into a type 1 macroprep ceramic hydroxylapatite column $(1 \times 10 \mathrm{~cm}, 40 \mu \mathrm{m}$; BioRad Laboratories, Hercules, CA, USA) previously equilibrated with $10 \mathrm{mM}$ sodium phosphate, $\mathrm{pH} 6.8$, and a flow rate of $0.5 \mathrm{~mL} / \mathrm{min}$. An eluted fraction showing a major protein on SDS-PAGE was concentrated in PBS ( $\mathrm{pH}$ 7.4) using a $5 \mathrm{kDa}$ cutoff membrane filter device (Vivaspin; Sartorius, Göttingen, Germany) and subsequently loaded onto a gel filtration column (SEC, hi Prep 26/60 Sephacryl S-100; Amersham Laboratories, Piscataway, NJ, USA). The purification procedure was carried out at room temperature at a flow rate of $0.5 \mathrm{ml} / \mathrm{min}$ using fast protein liquid chromatography (Amersham Laboratories, Piscataway, NJ, USA). Elution was performed isocratically using $\mathrm{PBS}$ at $\mathrm{pH}$ 7.4. The bioactive fraction after gel filtration was identified using an in vivo llama ovulation bioassay (17).

\section{Granulosa Cell Collection}

Non-pregnant, non-lactating female llamas $(n=48) \geq 6$ years of age and weighing 120-150 kg were used from April to June. Llamas were submitted to transvaginal ultrasound-guided follicle ablation of all ovarian follicles $\geq 5 \mathrm{~mm}$ using a 19-gauge needle attached to a $5 \mathrm{MHz}$ convex-array transducer to synchronize follicular wave emergence as described previously (19). The llamas were examined daily by transrectal ultrasonography using a 7.5-MHz linear-array transducer (Aloka SSD-500; Aloka Co., Ltd., Tokyo, Japan) to detect the emergence of a new preovulatory follicle. When a growing follicle $\geq 8 \mathrm{~mm}$ in diameter was detected $(17,18,20)$, llamas were submitted to transvaginal ultrasound-guided follicle aspiration using a $5.0-\mathrm{MHz}$ convexarray ultrasound transducer coupled to a 19-gauge needle as described previously $(19,21,22)$ to collect granulosa cells by flushing the preovulatory follicle.

\section{Primary Culture of llama Granulosa Cells}

Primary culture of llama granulosa cells was performed as previously described (10). Chemicals and reagents were 
purchased from Sigma-Aldrich Co., St. Louis, MO, USA, unless otherwise stated. In brief, follicular fluid collected from an individual female was centrifuged at $400 \times \mathrm{g}$ for $10 \mathrm{~min}$. The cell pellet was then resuspended in $2 \mathrm{ml}$ of Ham's F-12/DMEM and centrifuged again at 1,200 $\times \mathrm{g}$ for $45 \mathrm{~min}$ in a $3 \mathrm{ml} 50 \%$ Percoll column to separate granulosa cells from erythrocytes and interstitial cells. Purified granulosa cells were collected from the top of the Percoll column and washed twice by centrifugation at $400 \mathrm{x}$ g for $6 \mathrm{~min}$. Because a low number of granulosa cells were collected from individual animals, it was necessary to pool three animals after Percoll purification to get one biological sample. Granulosa cells were plated into 24-well culture plates (at $1 \times 10^{5}$ cells/well) in Ham's F-12/DMEM supplemented with $10 \%$ fetal bovine serum and antibiotics (penicillin/streptomycin and gentamicin) and incubated in an atmosphere of $95 \%$ air, $5 \%$ of $\mathrm{CO}_{2}$ at $38^{\circ} \mathrm{C}$ and high humidity for $48 \mathrm{~h}$. After $80 \%$ of confluence, the medium was replaced with serum-free Ham's F-12/DMEM and cells were treated with (i) control PBS, (ii) DMSO plus $10 \mu \mathrm{M}$ of the MAPK inhibitor U0126 (Cell Signaling Technologies, Beverly, MA, USA), (iii) $30 \mathrm{ng} / \mathrm{ml}$ of LH (LutropinV; Vétoquinol Canada Inc., Lavaltrie, QC, Canada), (iv) $50 \mathrm{ng} / \mathrm{ml}$ of purified llama $\beta$-NGF, and (v) purified llama $\beta$-NGF plus $10 \mu \mathrm{M}$ the MAPK inhibitor U0126 (added $30 \mathrm{~min}$ prior to $\beta$-NGF and remained for the whole period of treatment).

Five biological samples were used in both gene expression and progesterone secretion experiments $(n=15$ llamas in each experiment); for each time and treatment, each biological sample was plated in 4 wells (i.e., experimental replicates) and treated as indicated above. For gene expression, cells were treated for 10 or $20 \mathrm{~h}$; this time course was based on a previous report (10), in which significant changes in mRNA expression of STAR and VEGFA in primary culture of granulosa cells treated with $\beta$-NGF were detected.

\section{RNA Isolation and Real-Time PCR (Q-PCR) Analysis}

Total RNA was extracted from granulosa cells using Trizol (Invitrogen Life Technologies, Carlsbad, CA, USA) according to the manufacturer's recommendations. The purity of the samples was analyzed using the Nanodrop 1000 (Thermo Fisher Scientific, Inc., Wilmington, DE, USA). One microgram of total RNA was converted to complementary DNA (cDNA) using the kit AffinityScript Q-PCR cDNA Synthesis (Agilent Technologies, Inc., Santa Clara, CA, USA) and Oligo-dT as per the manufacturer's instructions.

Brilliant III Ultra-Fast SYBR ${ }^{\circledR}$ Q-PCR master mix (Agilent Technologies, Inc., Santa Clara, CA, USA) was used to detect and quantitate the transcripts. Samples were run in triplicate and amplified in a QuantStudio 3 RT-PCR (Applied Biosystems, Foster City, CA, USA) thermocycler using the following thermal cycle conditions: one cycle at $95^{\circ} \mathrm{C}$ for $3 \mathrm{~min}, 40$ cycles of $95^{\circ} \mathrm{C}$ for $5 \mathrm{~s}, 60^{\circ} \mathrm{C}$ for $30 \mathrm{~s}$, and $72^{\circ} \mathrm{C}$ for $1 \mathrm{~min}$. The coefficient of variation between samples ranged from 0.03 to 0.1 depending on the treatment. Data were analyzed using the thermocyclerassociated software. For each sample, cycle threshold values for the assayed transcripts were normalized for total input cDNA (10 ng) concentrations using cycle threshold values for transcripts for the "normalizer" housekeeping gene, large ribosomal protein (RPLP0; (23)). The normalized values in each experiment were compared to a "calibrator" sample to determine the relative increase in the amount of the transcript. Primers for PCR were designed using Primer Express Software (PE Biosystems, Foster City, CA, USA). Llama primers for steroidogenic enzymes, $V E G F A$, and RPLPO transcripts and their expected size of amplified products and sequences have already been tested and previously described $(9,10)$. The accession numbers of gen data are shown in Supplementary Table 1. Primer sets for transcript amplification were used at a final concentration of $250 \mathrm{nM}$ each. Data was analyzed using the thermocycler-associated software. Additionally, following amplification, the melting curves for the products were generated to ensure that the product represents a homogenous species.

\section{Progesterone Secretion From Primary Culture of llama Granulosa Cells}

Progesterone concentration was determined from the primary culture of llama granulosa cells as previously described (10). Briefly, the procedure for follicular synchronization and aspiration, granulosa cell collection, and treatments were similar to the described above. However, for progesterone secretion, granulosa cells were cultured for $48 \mathrm{~h}$ after confluence. After the incubation period, the media was collected and stored at $-20^{\circ} \mathrm{C}$ until it was assayed for progesterone. Progesterone concentration was determined by a solid-phase radioimmunoassay kit (RIACT KIP1458; DIASource ImmunoAssays SA Louvain-la-Neuve, Belgium) as previously reported (10). The intra-assay coefficient of variation was $0.26-3.57 \%$, the minimum detectable limit $0.05 \mathrm{ng} / \mathrm{ml}$, coefficient of variation of internal standard $<3.87 \%$, the limit of quantification observed for the assay was $0.45 \mathrm{ng} / \mathrm{ml}$.

\section{MAPK/ERK Activity in Primary Granulosa Cells Culture}

From 6 biological samples $(n=18$ llamas total), 4 experimental replicates per sample were used to determine the phosphorylation state of ERK1/2 after $\beta$-NGF treatment. In brief, llama granulosa cells were cultured as described above and treated with (i) control PBS, $50 \mathrm{ng} / \mathrm{ml}$ of $\beta$-NGF for (ii) 0 , (iii) 5 , (iv) 10 , and (v) $15 \mathrm{~min}, \beta$-NGF plus $10 \mu \mathrm{m}$ of MAPK inhibitor U0126 for (vi) 5, (vii) 10, and (viii) $15 \mathrm{~min}$. After the incubation period, cells $\left(1 \times 10^{6}\right)$ were lysed in $75 \mu \mathrm{l}$ of lysis buffer containing $150 \mathrm{mM} \mathrm{NaCl}, 50 \mathrm{mM}$ Tris- $\mathrm{HCl}, 1 \%$ Triton $\mathrm{X}-100$, $1 \mathrm{mM}$ EDTA, $1 \mathrm{mM}$ EGTA, $1 \mathrm{mM}$ phenylmethylsulfonyl fluoride, $1 \mathrm{~mm}$ sodium orthovanadate, $10 \mathrm{mg} / \mathrm{ml}$ leupeptin, $1.8 \mathrm{mg} / \mathrm{ml}$ aprotinin, $2 \mathrm{mM}$ sodium fluoride, $2 \mathrm{mM}$ sodium pyrophosphate, and $1 \mathrm{M}$ dithiothreitol. Ten micrograms of protein from each sample were size-fractionated by $12 \%$ SDS-PAGE and then transferred to nitrocellulose membrane (Bio-Rad Laboratories, Hercules, CA, USA). Nonspecific binding was blocked by incubating the membranes in PBS ( $\mathrm{pH} 7.4$ ) containing $2 \%$ non-fat dried milk and $0.2 \%$ Tween-20. Membranes were then incubated overnight at $4{ }^{\circ} \mathrm{C}$ with anti-phospho-MAPK p44/42 (ERK1/2) or anti-p44/42 (ERK1/2) rabbit polyclonal antibodies 
(1:1000; Cell Signaling Technologies, Beverly, MA, USA), followed by incubation at room temperature for $2 \mathrm{~h}$ with a goat anti-rabbit antibody conjugated with horseradish peroxidase (1:10,000; Cell Signaling Technologies, Beverly, MA, USA). The same membranes used to detect phosphorylated ERKs were stripped and blotted against total ERKs. Proteins were detected using an enhanced chemiluminescent detection system (PerkinElmer Life Sciences, Wellesley, MA, USA). The films were scanned and analyzed with a gel doc automated digitizing system (G:BOX Chemi XRQ; Syngene, Cambridge, UK).

\section{Statistical Analysis}

Data for gene, ERK protein expression, and progesterone concentration were analyzed by the PROC MIXED procedure, including the effect of treatment, time, replicate, and their interaction. The Dunnett test was used to compare gene expression of all treatments with the control groups. If significant differences were detected, means were compared among groups using Tukey's test. All data are reported as mean \pm SEM. Analyses were performed using the Statistical Analysis System software package SAS Learning Edition, version 4.1 (SAS Institute, Inc., Cary, NC, USA).

\section{RESULTS}

The effect of $\beta$-NGF or LH treatment on mRNA expression of steroidogenic enzymes and VEGFA in llama granulosa cells are shown in Figures 1, 2. There was a significant $(P \leq 0.01)$ increase of 3 beta-hydroxysteroid dehydrogenase (HSD3B1) and VEGFA mRNA abundance in cells treated with $\beta$-NGF or LH after $10 \mathrm{~h}$ (Figures 1C,E). After $20 \mathrm{~h}$, the mRNA abundance of STAR and CYP11A1 (P450scc) steroidogenic enzymes also significantly increased; the HSD $3 B 1$ and VEGFA mRNA transcripts remained upregulated (Figures 2B-E). As expected, neither $\beta$-NGF nor LH affected the mRNA expression of cytochrome $\mathrm{P} 450$ aromatase (P450arom encoded by CYP19A1) that is involved in estradiol synthesis (Figures 1A, 2A).

The addition of the MAPK inhibitor U0126 prior to the $\beta$ NGF treatment downregulated $(\mathrm{P} \leq 0.01)$ the mRNA abundance of all steroidogenic enzymes and VEGFA transcripts after $10 \mathrm{~h}$ (Figures 1A-E). Most of the genes remained downregulated after 20 h, except CYP19A1 (P450arom), which was not significantly different from control (Figures 2B-E). Cells treated with the U0126 inhibitor alone did not significantly change the mRNA expression of steroidogenic enzymes and VEGFA at any time.

Progesterone secretion from llama granulosa cells was significantly $(P \leq 0.01)$ increased $48 \mathrm{~h}$ after $\beta$-NGF or LH treatment; the addition of the MAPK inhibitor U0126 prior to the $\beta$-NGF treatment prevented the increase of progesterone secretion as shown in Figure 3.

Western blotting of llama granulosa cells treated with $50 \mathrm{ng} / \mathrm{ml}$ of $\beta$-NGF showed a significant $(P \leq 0.01)$, timedependent increase of ERK2 phosphorylation after 5, 10, and 15 min of treatment; this increase exhibited a reduced intensity for ERK1. The addition of the inhibitor U0126 prior to $\beta$-NGF administration significantly $(P \leq 0.01)$ decreased the state of ERK1/2 phosphorylation (Figures 4A,B).

\section{DISCUSSION}

Neurotrophins, including $\beta$-NGF, are classically known for their role in neural growth and survival (24), but the relatively recent isolation and purification of $\beta$-NGF from the seminal plasma of llamas $(17,18)$ and also other species $(25)$ has led to revisiting their roles in reproductive biology, emerging new ones $(18,26)$. Previous studies have linked NGF to ovarian development and innervation (27-29), but in the last years, evidence (1) indicates that $\beta$-NGF is involved in CL formation.

In this study, we investigated whether purified llama $\beta$ NGF exerts luteotropic effects on a primary culture of llama granulosa cells collected from preovulatory follicles. We show that llama granulosa cells treated with $\beta$-NGF upregulates steroidogenic enzymes and angiogenic transcripts after 10 and $20 \mathrm{~h}$ of treatment, and that this response is mediated by the ERK1/2 signaling pathway. Also, the $\beta$-NGF-induced increase of progesterone concentration is prevented by the MAPK inhibitor U0126, confirming that the biological actions of $\beta$-NGF are mediated, at least in part, by this pathway.

The first evidence of NGF receptors in the ovary was given by Dissen et al. (29), who detect low-affinity receptors in theca and also, to a lesser extent in granulosa cells of antral and preantral follicles of peripubertal rats. Subsequent studies confirm the expression of the high-affinity trkA NGF receptor in granulosa and theca cells of several species, including cows (14), rats (30), and humans (15). Binding of trkA receptors by its ligand $\beta$-NGF is known to elicit activation of the ERK1/2 signaling pathway $(31,32)$, including in granulosa cells $(33)$. In line with this, our results show that the sole application of purified llama $\beta$-NGF to primary cultured llama granulosa cells results in activation of the ERK1/2 signaling pathway.

Expression of different steroidogenic enzymes is crucial for the ability of cells to synthesize steroids from cholesterol and its precursors. In the present study, we detect upregulation of HSD3B1 mRNA transcript after $10 \mathrm{~h}$ of both $\beta$-NGF and $\mathrm{LH}$ treatments; and after $20 \mathrm{~h}$, all the transcripts of the steroidogenic enzymes involved in progesterone secretion are also upregulated. Few studies address the effect of $\beta$-NGF on these enzymes; we have previously reported that $\beta$-NGF enhanced STAR, $C Y P 11 A 1$, and HSD3B1 mRNA transcripts in llama granulosa cells in vivo (10), but these followed a distinct time expression pattern. Recently, Stewart et al. (6) report that the expression of steroidogenic enzymes in heifer luteal cells seems to be relatively similar to that reported here, resulting in increased circulating progesterone, albeit the expression of $H S D 3 B 1$ - which converts pregnenolone to progesterone-was unaffected.

In spontaneous ovulators, it can be expected that granulosa cells collected by follicle aspiration from a preovulatory follicle may exhibit some degree of luteinization due to the effect of the increasing $\mathrm{LH}$ release occurring at the end of the follicular phase. Conversely, in llamas, LH is released in response to the copulatory stimulus as this species is an induced ovulator. In line with this, Silva et al. (9) report that, in llamas treated with control PBS but not $\beta$-NGF or GnRH, plasma progesterone concentrations remain basal for up to 10 days. Although, in the present study, we did not evaluate the ratio of progesterone: 


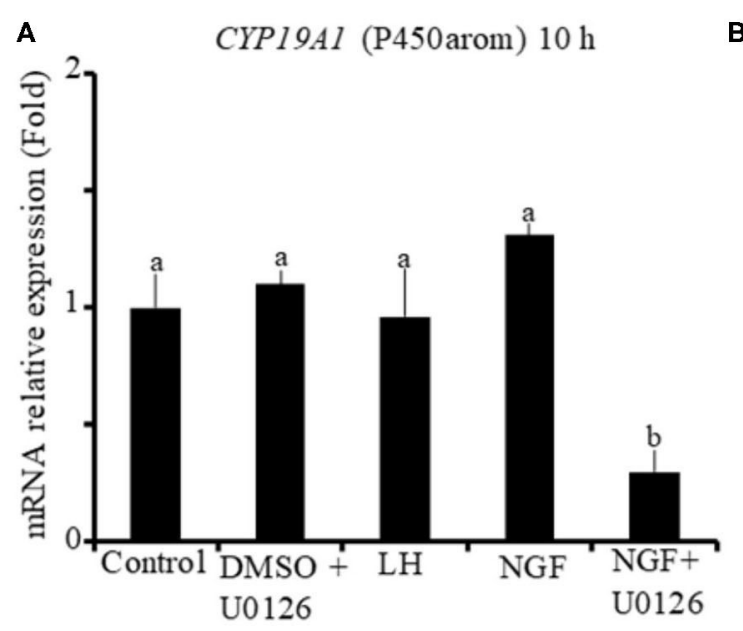

C $H S D 3 B 110 \mathrm{~h}$

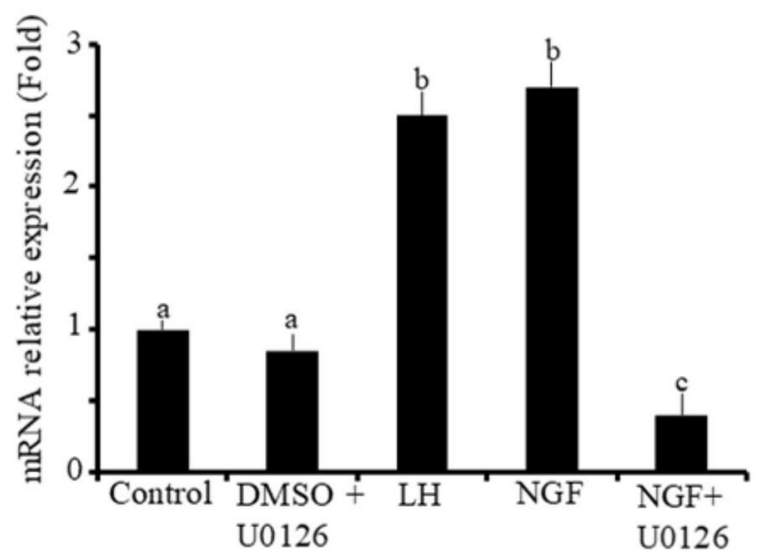

B

D
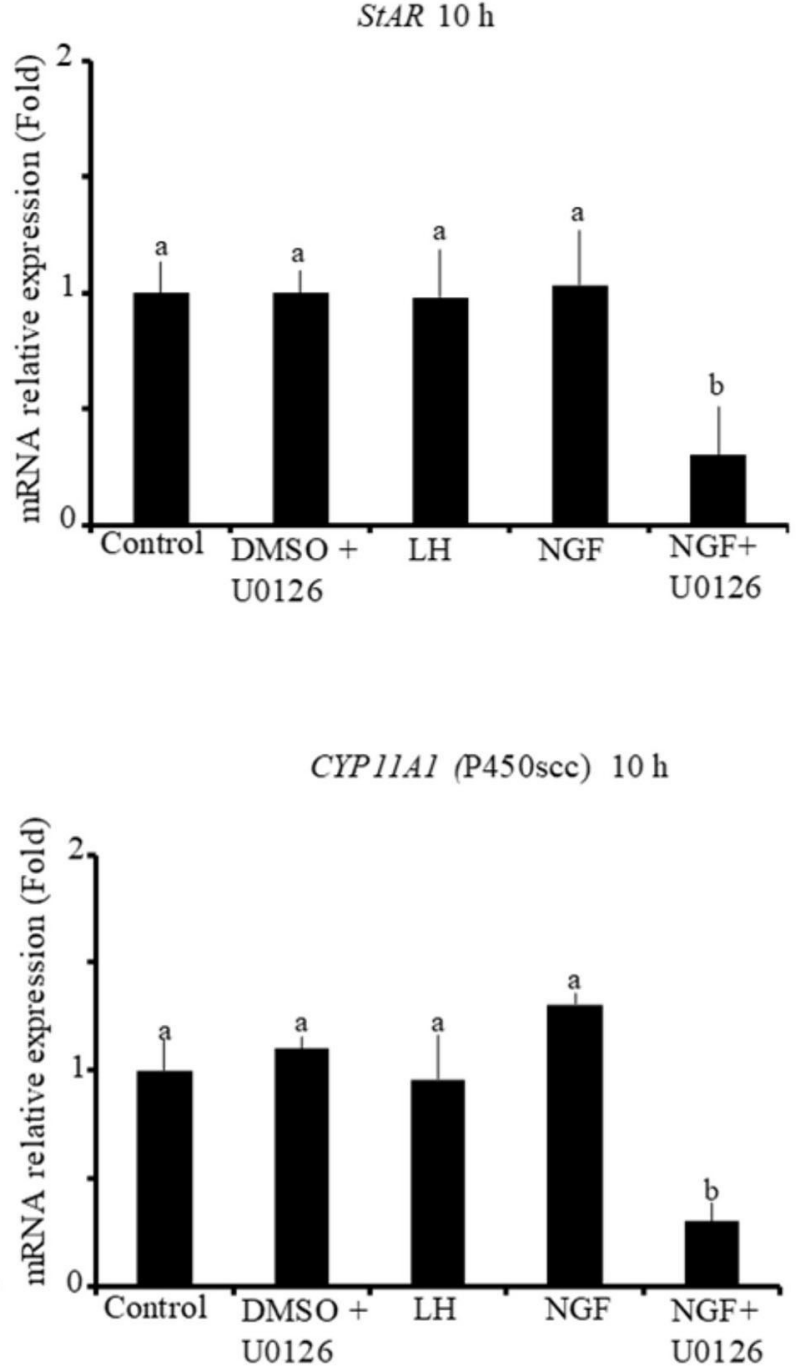

E

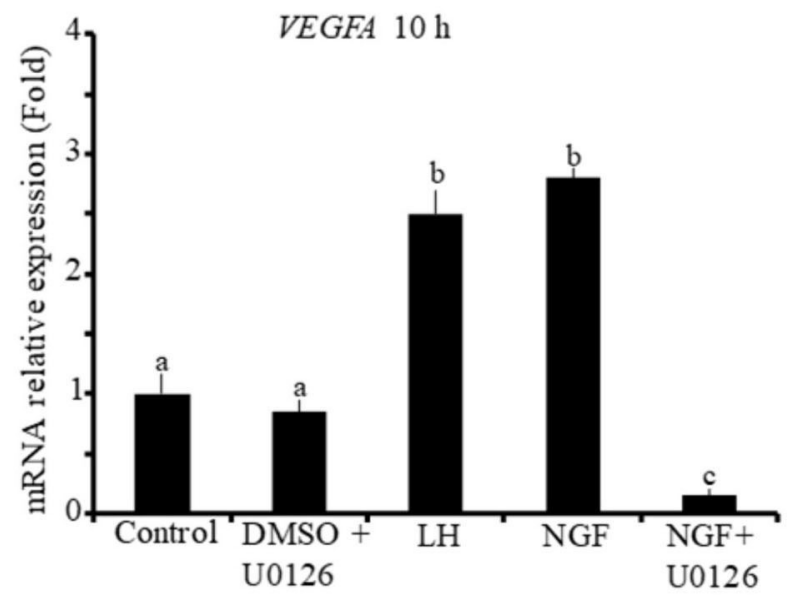

FIGURE 1 | Relative mRNA abundance of (A) CYP19A1 (P450arom), (B) STAR, (C) HSD3B1, (D) CYP11A1 (P450scc) steroidogenic enzymes, and (E) VEGFA angiogenic factor in primary llama granulosa cell culture treated for $10 \mathrm{~h}$. Mean + SEM; $n=5$ biological samples; within each biological sample, 4 experimental replicates were performed; a, b, c superscripts indicate significant differences $(P \leq 0.01)$ between control and other groups. 


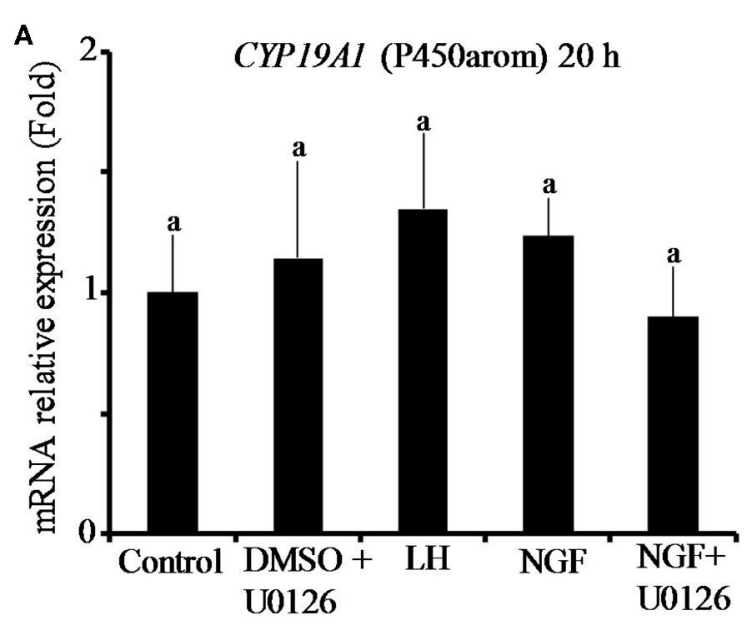

C

$H S D 3 B 120 \mathrm{~h}$

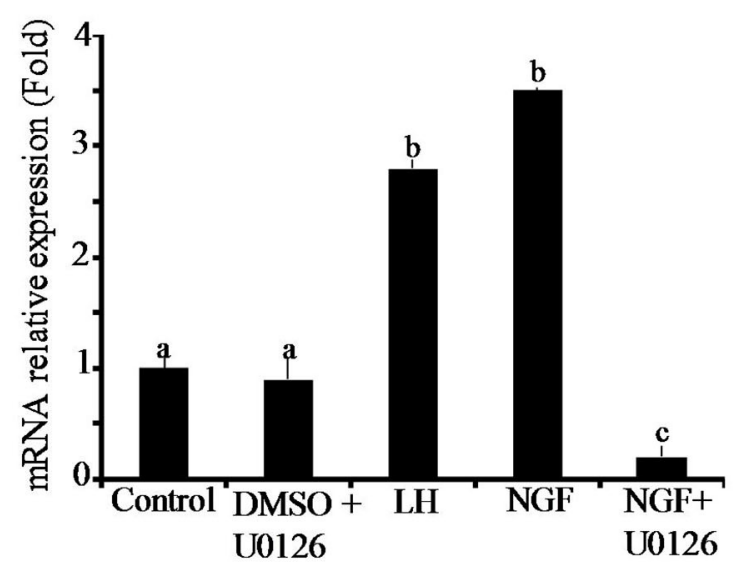

B

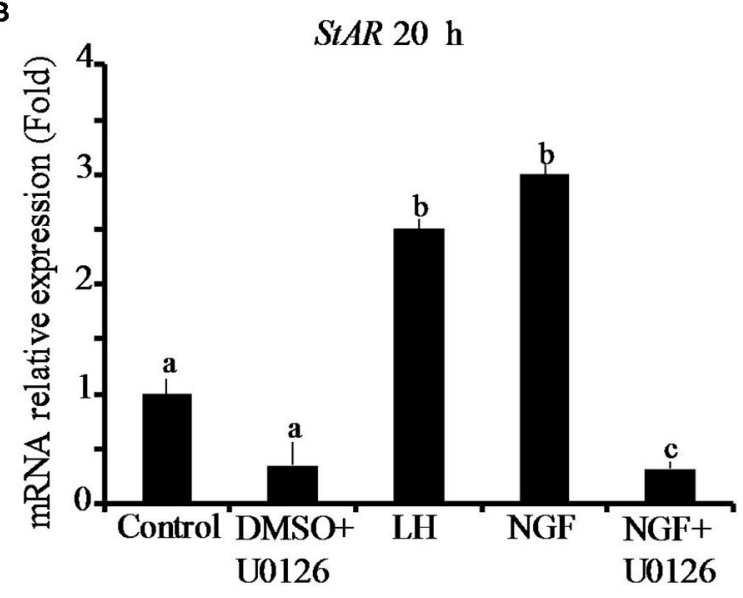

D

CYPIIAI (P450scc) $20 \mathrm{~h}$

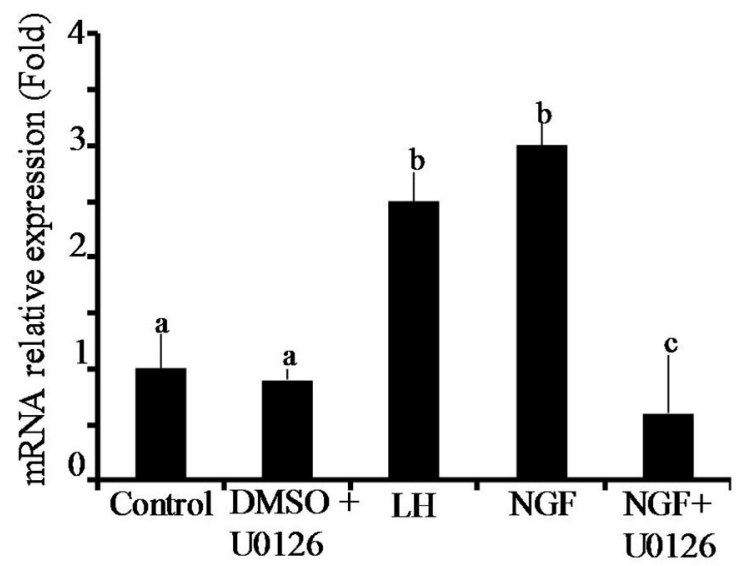

E

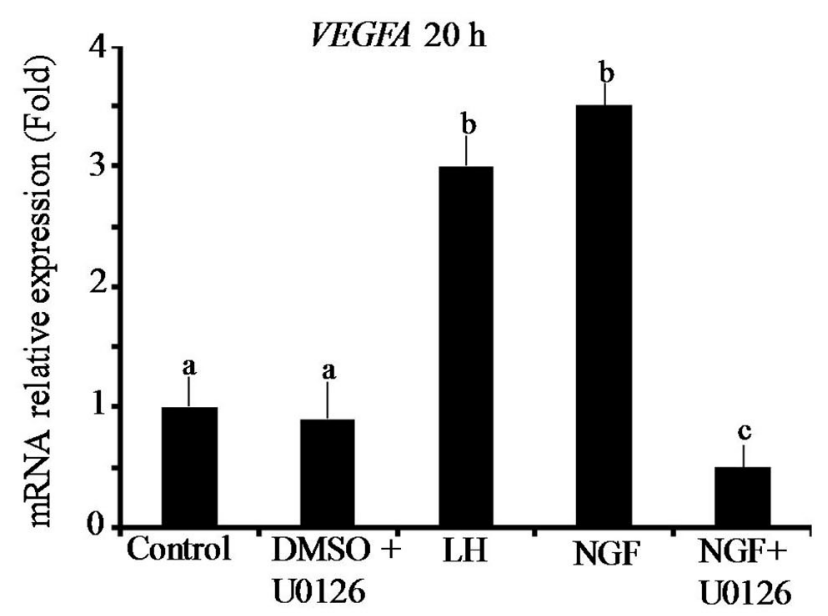

FIGURE 2 | Relative mRNA abundance of (A) CYP19A1 (P450arom), (B) STAR, (C) HSD3B1, (D) CYP11A1 (P450scc) steroidogenic enzymes, and (E) VEGFA angiogenic factor in primary llama granulosa cell culture treated for $20 \mathrm{~h}$. Mean $+\mathrm{SEM} ; n=5$ biological samples; within each biological sample, 4 experimental replicates were performed; a, b, c superscripts indicate significant differences $(P \leq 0.01)$ between control and other groups. 


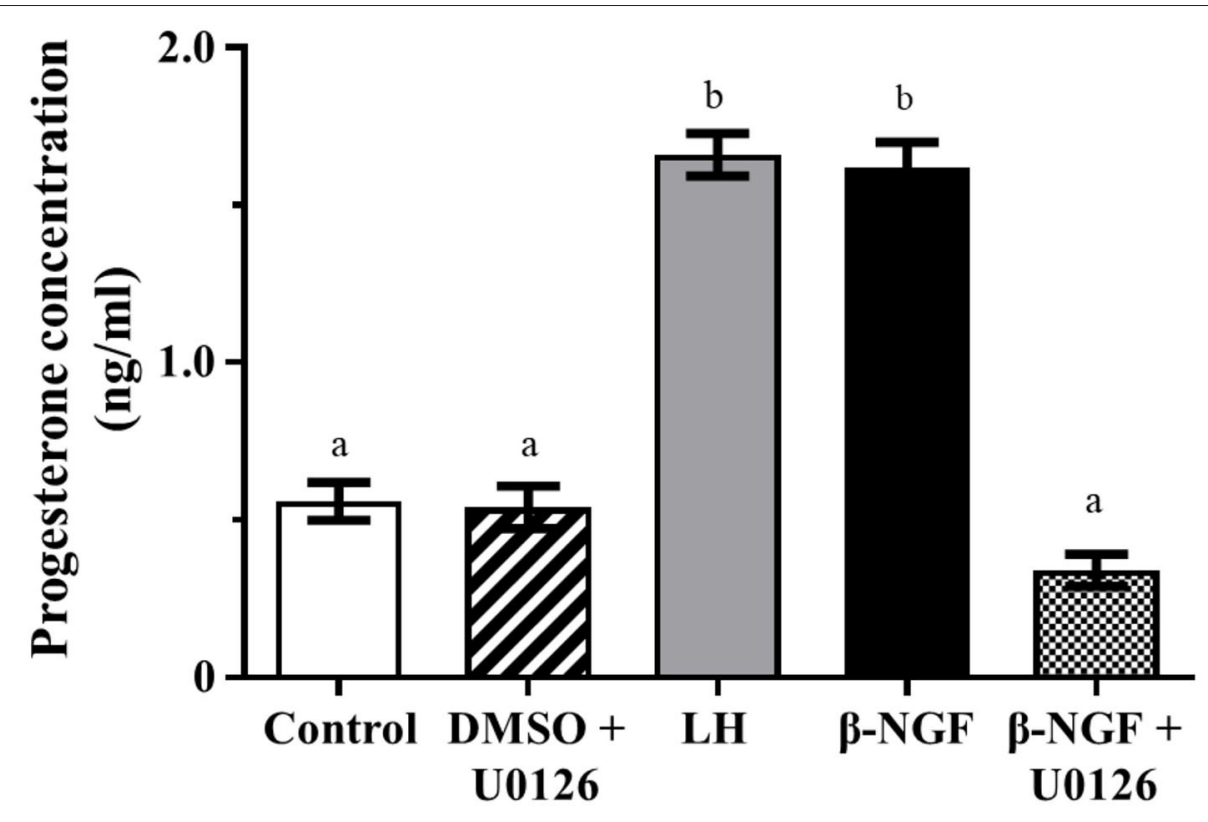

FIGURE 3 | Progesterone secretion from primary culture of llama granulosa cells after $48 \mathrm{~h}$. Mean \pm SEM; $n=6$ biological samples; within each biological sample, 4 experimental replicates were performed; a, b superscripts indicate significant differences $(P \leq 0.01)$ between control and other groups.

estradiol, we previously reported (10) a marked ratio increase from 0.2 to 0.8 in control and $\beta$-NGF-treated animals, respectively, and this shift to progesterone production occurred after 20 but not $10 \mathrm{~h}$ following $\beta$-NGF treatment. Finally, the persistent detection of CYP19A1 (P450arom catalyzing estradiol) reported in the present study also supports that the cells cultured here preserve their granulosa phenotype over the time analyzed, and thus, the effect of $\beta$-NGF on llama granulosa cells should be carefully interpreted as prosteroidogenic rather than luteinizing itself.

Time-dependent gene expression patterns of steroidogenic enzymes following $\mathrm{LH}$ have been detected in cultured bovine granulosa cells, resulting in enhanced expression of CYP11A1 (P450scc) and HSD3B1 transcripts; paradoxically, in vivo expression of these genes is reduced in granulosa cells collected after the LH surge when compared to those collected before $(34,35)$. The parallel gene expression profiles induced by $\beta$ NGF and LH reported here may be related to phosphorylation of ERK1/2, which also occurs following activation of $\mathrm{LH}$ receptors in preovulatory granulosa cells (36).

Interestingly, the application of the inhibitor U0126 alone did not affect gene expression, but its use combined with $\beta$-NGF downregulated virtually all steroidogenic and VEGFA transcripts in the llama granulosa cells. A plausible explanation could be that, once the EKR1/2 pathway was blocked, $\beta$-NGF exerts a paradox effect by activating (or causing predominance of) other transduction pathways that downregulate the constitutive expression of the genes analyzed here. For example, in some cell types, $\beta$-NGF-activating trkA receptors stimulate cell growth and survival, whereas the absence of trkA stimulates apoptosis via the low-affinity neurotrophin receptor, p75NTR (37). Expression of p75NTR is found in granulosa cells of humans (38) and squirrels (39); whether this is expressed in llama granulosa cells is unknown.

Consistent with our findings on intracellular pathways and gene expression, we also find that $\beta$-NGF application results in an ERK1/2-dependent progesterone synthesis in primary culture of llama granulosa cells. A previous study (40) reports that in vitro NGF microdialysis perfusion of cow luteal tissue but not in non-proliferative luteal cell culture, results in increased progesterone (and also local oxytocin) release from ovaries at early- and mid-luteal stage. This discrepancy between experimental conditions is likely to be related to cell culture settings as thecal cells plated in low but not high density also failed to secrete the steroids in response to NGF (14). Conversely to the evidence from llama and cows, in cultured human granulosa cells collected from preovulatory follicles, NGF application is shown to increase estradiol, whereas it decreases progesterone secretion (15). Perhaps there are speciesspecific variations on steroid output response to $\beta$-NGF in granulosa cells.

The CL is considered one of the most vascularized body structures; it receives the greatest rate of blood flow per unit of tissue compared to any organ of the body (41), and so angiogenesis plays an important role during the $\mathrm{CL}$ formation. The $\mathrm{LH}$ surge is considered a key signal to influence the expression of the VEGF that induces angiogenesis throughout the proliferation of preexistent endothelial cells (42). In human granulosa cells obtained from in vitro fertilization patients, NGF is shown to promote ovarian angiogenesis by enhancing the secretion of VEGF through the activation 
A

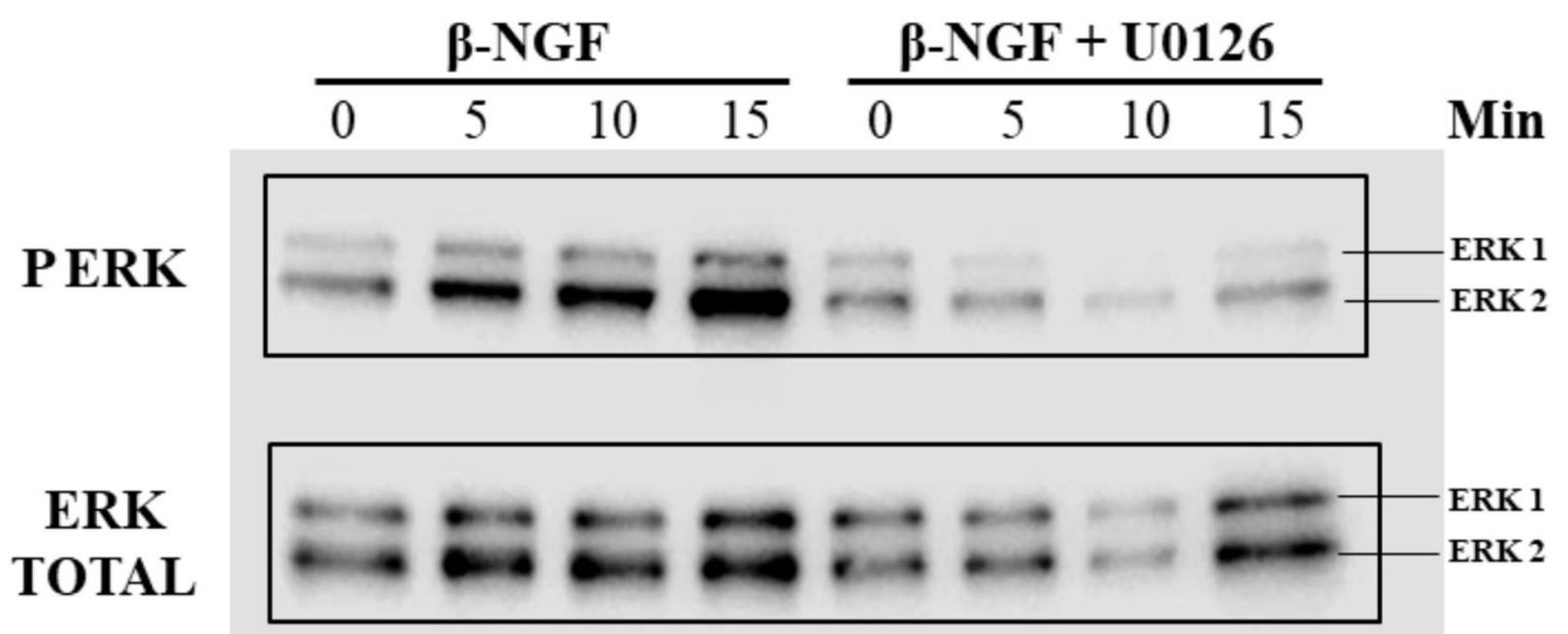

B

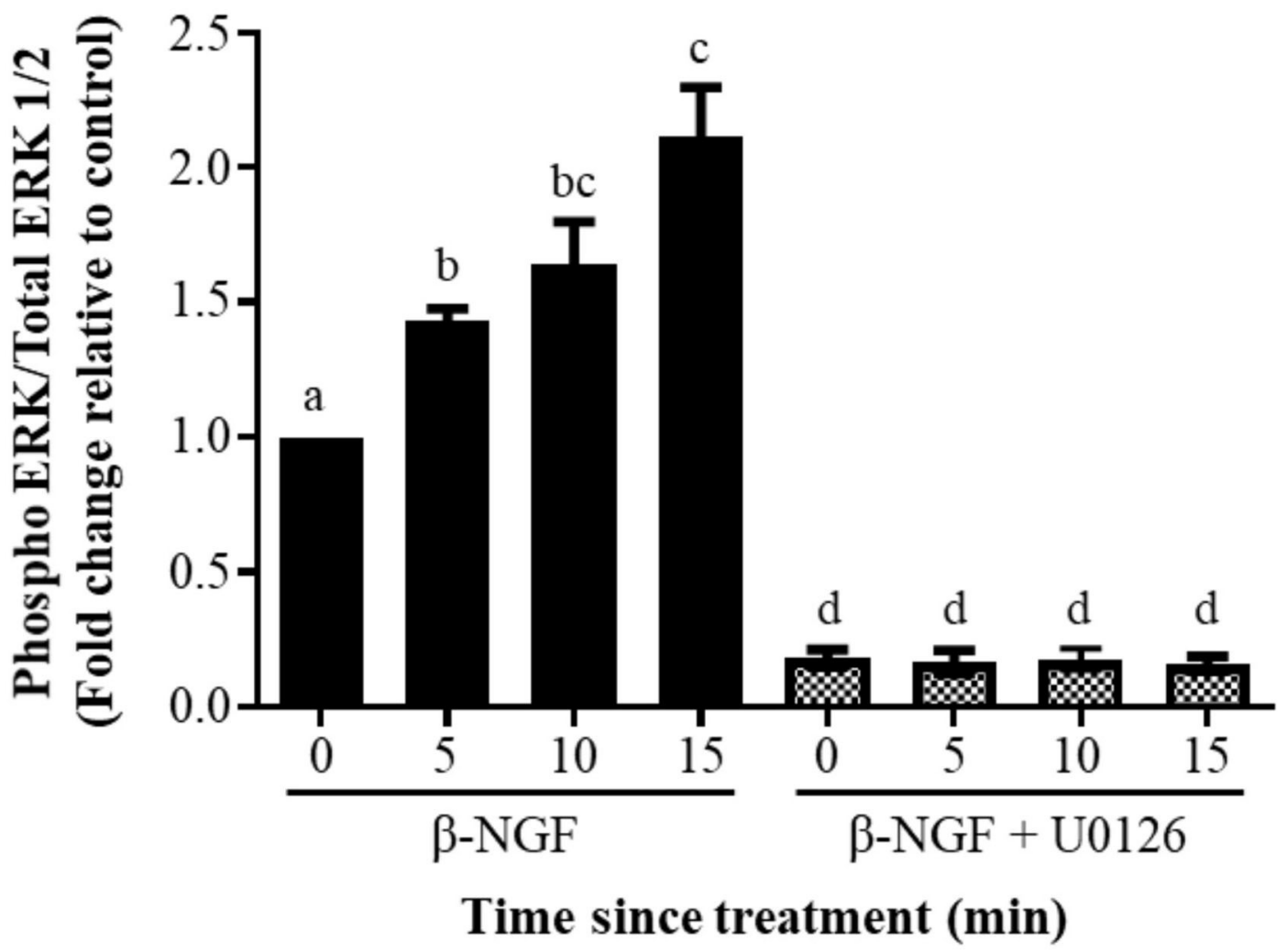

FIGURE 4 | $\beta$-NGF induces phosphorylation of ERK1/2 in llama granulosa cells in vitro. (A) Western blot showing that NGF induces a rapid, time-dependent phosphorylation of ERK2, and to lesser extent, expression of ERK1 by the same time intervals. (B) Densitometric analysis of the blot shown in (A), expressed as the ratio of phosphorylated ERK1/2 of total ERK. Values are mean $+\mathrm{SEM} ; n=6$ biological replicates. a, b, c, d superscripts indicate significant differences $(P \leq 0.01)$ between control and the other groups. 
of the ERK1/2 pathway (43). Similarly, we found that, in llama granulosa cells, VEGFA mRNA expression rapidly increases after $10 \mathrm{~h}$ to remain relatively stable after $20 \mathrm{~h}$ of $\beta$-NGF and LH treatments, and this increase was dependent on the ERK1/2 pathway. Enhancement of VEFG mRNA expression is also known to occur by different signaling pathways in other cell types (44); whether $\beta$-NGF also activates other pathways in llama granulosa cells remains to be determined.

Previous studies show that, in llamas, CL develops after ovulation induced by seminal plasma (2) or purified $\beta$-NGF $(7,8,18)$ and tended to be larger, regressed later, and produced twice as much progesterone than those resulting from $\mathrm{GnRH}$ treatments, supporting the notion that this effect might be related to the sustained $\mathrm{LH}$ release profile induced by $\beta$ NGF (7, 8, 17, 45). However, decreasing pharmacological doses of the $\mathrm{GnRH}$ analog, gonadorelin acetate, have been shown to affect the magnitude of the $\mathrm{LH}$ release in a dose-dependent fashion, but the consequent reduction in $\mathrm{LH}$ discharge had no effect on the CL diameter and plasma progesterone concentrations in llamas (46), indicating that the enhancement of luteal function induced by $\beta$-NGF occurs locally at the ovarian level rather than upstream on the classical LH mechanism.

In this in vitro study, both $\beta$-NGF and $\mathrm{LH}$ treatments equally increased genes involved in CL angiogenesis and steroid synthesis that resulted in a similar progesterone secretion, making it difficult to distinguish the contribution to the luteotropic effect of each hormone separately, and so it could be that, when acting $\beta$-NGF and $\mathrm{LH}$ together, there are synergic effects at the follicular level, similarly as shown to occur with $\mathrm{LH}$ and insulin administration in porcine granulosa cells in vitro $(47,48)$. In line with this notion, llamas in which ovulations were induced by $\beta$-NGF displayed enhanced expression of steroidogenic enzymes (9) and plasma progesterone concentrations (49) than those of ovulations stimulated by GnRH.

In summary, here we show and identify the intracellular pathway by which $\beta$-NGF exerts a direct luteotropic effect on ovarian tissue; however, further studies are required to determine whether synergic mechanisms exist that explain the $\beta$-NGF-related enhancement of luteal function and progesterone secretion reported in vivo.

\section{REFERENCES}

1. Silva M, Paiva L, Ratto MH. Ovulation mechanism in South American Camelids: the active role of $\beta$-NGF as the chemical signal eliciting ovulation in llamas and alpacas. Theriogenology. (2020) 150:280-7. doi: 10.1016/j.theriogenology.2020.01.078

2. Adams GP, Ratto MH, Huanca W, Singh J. Ovulation-inducing factor in the seminal plasma of alpacas and llamas. Biol Reprod. (2005) 73:452-7. doi: 10.1095/biolreprod.105.040097

3. Ratto MH, Huanca W, Singh J, Adams GP. Comparison of the effect of ovulation-inducing factor (OIF) in seminal plasma of llamas, alpacas, and bulls. Theriogenology. (2006) 66:1102-6. doi: 10.1016/j.theriogenology.2006.02.050

\section{DATA AVAILABILITY STATEMENT}

The datasets presented in this study can be found in online repositories. The names of the repository/ repositories and accession number(s) can be found in the article/Supplementary Material.

\section{ETHICS STATEMENT}

The animal study was reviewed and approved by University Bioethical Committee (Universidad Austral de Chile) in accordance with the Chilean Animal Protection Act (2009) and the University animal care protocols, and the Animal Bioethical Committee of CONICYT (Chilean National Council of Science and Technology).

\section{AUTHOR CONTRIBUTIONS}

$\mathrm{XV}$ and LP were responsible for the development of the primary culture of llama granulosa cells and the execution of RT-QPCR and western blots experiments. CU-L, MS, JG, VR, and MR were responsible for granulosa cell collection in llamas using ultrasound-guided follicular aspiration and interpretation of gene expression and western blot data. XV, MR, SA, LS, and MA were responsible for the experimental design of the study and interpretation of gene expression and western blot data. MR and LP were major contributors in writing and editing of the manuscript. All authors participated actively in the analyses, interpretation of the data, read, and approved the final manuscript. All authors contributed to the article and approved the submitted version.

\section{FUNDING}

This study was supported by the Agencia Nacional de Investigacion y Desarrollo (ANID) of Chile, grants FONDECYT Postdoctorado 3200439 (LP), and FONDECYT Regular 1160934 (MR).

\section{SUPPLEMENTARY MATERIAL}

The Supplementary Material for this article can be found online at: https://www.frontiersin.org/articles/10.3389/fvets. 2020.586265/full\#supplementary-material

4. Fernandez A, Ulloa-Leal C, Silva M, Norambuena C, Adams GP, Guerra $\mathrm{M}$, et al. The effect of repeated administrations of llama ovulation-inducing factor (OIF/NGF) during the peri-ovulatory period on corpus luteum development and function in llamas. Anim Reprod Sci. (2014) 149:345-52. doi: 10.1016/j.anireprosci.2014.08.001

5. Ulloa-Leal C, Bogle OA, Adams GP, Ratto MH. Luteotrophic effect of ovulation-inducing factor/nerve growth factor present in the seminal plasma of llamas. Theriogenology. (2014) 81:1101-7. doi: 10.1016/j.theriogenology.2014.01.038

6. Stewart JL, Stella S, Cunha LL, Dias NW, Canisso IF, Mercadante VRG, et al. Administration of nerve growth factor- $\beta$ to heifers with a preovulatory follicle enhanced luteal formation and function and promoted $\mathrm{LH}$ release. Theriogenology. (2020) 148:37-47. doi: 10.1016/j.theriogenology.2020.02.040 
7. Silva M, Smulders JP, Guerra M, Valderrama XP, Letelier C, Adams GP, et al. Cetrorelix suppresses the preovulatory LH surge and ovulation induced by ovulation-inducing factor (OIF) present in llama seminal plasma. Reprod Biol Endocrinol. (2011) 9:74. doi: 10.1186/1477-7827-9-74

8. Silva M, Nino A, Guerra M, Letelier C, Valderrama XP, Adams GP, et al. Is an ovulation-inducing factor (OIF) present in the seminal plasma of rabbits? Anim Reprod Sci. (2011) 127:213-21. doi: 10.1016/j.anireprosci.2011.08.004

9. Silva M, Ulloa-Leal C, Valderrama XP, Bogle OA, Adams GP, Ratto MH. Nerve growth factor from seminal plasma origin ( $\operatorname{sp} \beta-\mathrm{NGF)}$ increases $\mathrm{CL}$ vascularization and level of mRNA expression of steroidogenic enzymes during the early stage of Corpus Luteum development in llamas. Theriogenology. (2017) 103:69-75. doi: 10.1016/j.theriogenology.2017.07.041

10. Valderrama XP, Silva M, Goicochea J, Ratto MH. The effect of seminal plasma $\beta$-NGF on follicular fluid hormone concentration and gene expression of steroidogenic enzymes in llama granulosa cells. Reprod Biol Endocrinol. (2019) 17:60. doi: 10.1186/s12958-019-0504-9

11. Maranesi M, Petrucci L, Leonardi L, Piro F, García-Rebollar P, Millán $\mathrm{P}$, et al. New insights on a NGF-mediated pathway to induce ovulation in rabbits (Oryctolagus cuniculus). Biol Reprod. (2018) 98:634-43. doi: 10.1093/biolre/ioy041

12. Carrasco R, Singh J, Adams GP. The dynamics of trkA expression in the bovine ovary are associated with a luteotrophic effect of ovulation-inducing factor/nerve growth factor (OIF/NGF). Reprod Biol Endocrinol. (2016) 14:4757. doi: 10.1186/s12958-016-0182-9

13. Dissen GA, Romero C, Paredes A, Ojeda S. Neurotrophic control of ovarian development. Microsc Res Tech. (2002) 59:509-15. doi: 10.1002/jemt.10227

14. Dissen GA, Parrot JA, Skinner MK, Hill DF, Costa ME, Ojeda SR. Direct effects of nerve growth factor on thecal cells from antral ovarian follicles. Endocrinology. (2000) 141:4736-50. doi: 10.1210/endo.141.12.7850

15. Salas C, Julio-Pieper M, Valladares M, Pommer R, Vega M, Mastronardi $\mathrm{C}$, et al. Nerve growth factor-dependent activation of trkA receptors in the human ovary results in synthesis of follicle-stimulating hormone receptors and estrogen secretion. J Clin Endocrino Metab. (2006) 91:2396-403. doi: 10.1210/jc.2005-1925

16. Berland MA, Ulloa-Leal C, Barría M, Wright H, Dissen GA, Silva ME, et al. Seminal plasma induces ovulation in llamas in the absence of a copulatory stimulus: role of nerve growth factor as an ovulation-inducing factor. Endocrinology. (2017) 157:3224-32. doi: 10.1210/en.2016-1310

17. Ratto MH, Delbaere LTJ, Leduc YA, Pierson RA, Adams GP. Biochemical isolation and purification of ovulation-inducing factor (OIF) in seminal plasma of llamas. Repro Biol Endocrinol. (2011) 9:24. doi: 10.1186/1477-7827-9-24

18. Ratto MH, Leduc Y, Valderrama XP, van Straaten K, Delbaere L, Pierson R, et al. The nerve of ovulation inducing factor. Proc Natl Acad Sci USA. (2012) 109:15042-7. doi: 10.1073/pnas.1206273109

19. Ratto MH, Singh J, Huanca H, Adams GP. Ovarian follicular wave synchronization and fixed-time natural mating in llamas. Theriogenology. (2003) 60:1645-56. doi: 10.1016/S0093-691X(03)00176-6

20. Urra F, Ratto MH, Silva $M$. Evaluation of mating, intrauterine deposition of raw seminal plasma or seminal plasma purified $\beta$-NGF on endometrial vascularization in llamas. Theriogenology. (2018) 125:18-23. doi: 10.1016/j.theriogenology.2018.10.007

21. Ratto $\mathrm{MH}$, Singh J, Huanca $\mathrm{H}$, Adams GP. In vivo and in vitro maturation of llama oocyte. Theriogenology. (2004) 63:2445-57. doi: 10.1016/j.theriogenology.2004.09.053

22. Berland MA, von Baer A, Ruiz J, Parraguez VH, Morales P, Adams GP, et al. In vitro fertilization and development of cumulus oocytes complexes collected by ultrasound-guided follicle aspiration in superstimulated llamas. Theriogenology. (2011) 75:1482-8. doi: 10.1016/j.theriogenology.2010.11.047

23. Luo W, Gumen A, Haughiam JM, Wiltbank MC. The role of Luteinizing hormone in regulating gene expression during selection of the dominant follicle in cattle. Biol Reprod. (2011) 84:369-78. doi: 10.1095/biolreprod.110.085274

24. Huang EJ, Reichardt LF. Neurotrophins: roles in neuronal development and function. Annu Rev Neurosci. (2001) 24:677-736. doi: 10.1146/annurev.neuro.24.1.677

25. Bogle O, Carrasco R, Ratto MH, Singh J, Adams GP. Source and localization of ovulation- inducing factor/nerve growth factor in male reproductive tissues among mammalian species. Biol Reprod. (2018) 99:1194204. doi: 10.1093/biolre/ioy149

26. Pinet-Charvet C, Fleurot R, Derouin-Tochon F, de Graaf S, Druart X, Tsikis G, et al. Beta-nerve growth factor stimulates spontaneous electrical activity of in vitro embryonic mouse GnRH neurons through a P75 mediated-mechanism. Sci Rep. (2020) 10:10654. doi: 10.1038/s41598-020-67665-4

27. Lara HE, Hill DF, Katz KH, Ojeda SR. The gene encoding nerve growth factor is expressed in the immature rat ovary: effect of denervation and hormonal treatment. Endocrinology. (1990) 126:357-63. doi: 10.1210/endo-126-1-357

28. Lara HE, McDonald JK, Ojeda SR. Involvement of nerve growth factor in female sexual development. Endocrinology. (1990) 126:364-75. doi: 10.1210/endo-126-1-364

29. Dissen GA, Hill DF, Costa ME, Ma YJ, Ojeda SR. Nerve growth factor receptors in the peripubertal rat ovary. Mol Endocrinol. (1991) 5:1642-50. doi: 10.1210/mend-5-11-1642

30. Dissen GA, Hill DF, Costa ME, Les Dees CW, Lara HE, Ojeda SR. A role for trkA nerve growth factor receptors in mammalian ovulation. Endocrinology. (1996) 137:198-209. doi: 10.1210/endo.137.1.8536613

31. Huang EJ, Reichardt LF. Trk receptors: roles in neuronal signal transduction. Annu Rev Biochem. (2003) 72:609-42. doi: 10.1146/annurev.biochem.72.121801.161629

32. Van Kanegan MJ, Strack S. The protein phosphatase 2A regulatory subunits B'beta and B'delta mediate sustained TrkA neurotrophin receptor autophosphorylation and neuronal differentiation. Mol Cell Biol. (2009) 29:662-74. doi: 10.1128/MCB.01242-08

33. Moore RK, Otsuka F, Shimasaki S. Role of ERK1/2 in the differential synthesis of progesterone and estradiol by granulosa cells. Biochem Biophys Res Commun. (2001) 289:796-800. doi: 10.1006/bbrc.2001.6052

34. Voss AK, Fortune JE. Levels of messenger ribonucleic acid for cholesterol sidechain cleavage cytochrome P-450 and 3 beta-hydroxysteroid dehydrogenase in bovine preovulatory follicles decrease after the luteinizing hormone surge. Endocrinology. (1993) 132:888-94. doi: 10.1210/endo.132.2.8425501

35. Voss AK, Fortune JE. Levels of messenger ribonucleic acid for cytochrome P450 17 alpha-hydroxylase and P450 aromatase in preovulatory bovine follicles decrease after the luteinizing hormone surge. Endocrinology. (1993) 132:2239-45. doi: 10.1210/endo.132.5.8477668

36. Salvador LM, Maizels E, Hales DB, Miyamoto E, Yamamoto $H$, Hunzicker-Dunn M. Acute signaling by the LH receptor is independent of protein kinase C activation. Endocrinology. (2002) 143:2986-94. doi: 10.1210/endo.143.8.8976

37. Casaccia-Bonnefil P, Kong H, Chao MV. Neurotrophins: the biological paradox of survival factors eliciting apoptosis. Cell Death Differ. (1998) 5:35764. doi: 10.1038/sj.cdd.4400377

38. Buyuk E, Santoro N, Cohen HW, Charron MJ, Jindal S. Reduced neurotrophin receptor tropomyosin-related kinase A expression in human granulosa cells: a novel marker of diminishing ovarian reserve. Fertil Steril. (2011) 96:474-8. doi: 10.1016/j.fertnstert.2011.05.017

39. Li B, Sheng X, Bao L, Huang S, Li Q, Liu Y, et al. Seasonal changes in expression of nerve growth factor and its receptors TrkA and p75 in the ovary of wild ground squirrel (Citellus dauricus Brandt). J Ovarian Res. (2014) 7:3. doi: 10.1186/1757-2215-7-3

40. Miyamoto A, Okuda K, Schweigert FJ, Schams D. Effects of basic fibroblast growth factor, transforming growth factor- and nerve growth factor on the secretory function of the bovine corpus luteum in vitro. J Endocrinol. (1992) 135:103-14. doi: 10.1677/joe.0.1350103

41. Wiltbank MC, Dysko RC, Gallagher KP, Keyes PL. Relationship between blood flow and steroidogenesis in the rabbit corpus luteum. J Reprod Fertil. (1988) 84:513-20. doi: 10.1530/jrf.0.0840513

42. Dvorak HF, Nagy JA, Feng D, Brown LF, Dvorak AM. Vascular permeability factor/vascular endothelial growth factor and the significance of microvascular hyperpermeability in angiogenesis. In: Claesson-Welsh L, editor. Vascular Growth Factors and Angiogenesis. Current Topics in Microbiology and Immunology. Berlin: Springer (1999). p. 97-132.

43. Julio-Pieper M, Lozada P, Tapia V, Vega M, Miranda C, Vantman D, et al. Nerve growth factor induces vascular endothelial growth factor expression in granulosa cells via a trkA receptor/mitogen-activated protein Kinaseextracelullarly regulated kinase 2-dependent pathway. J Clin Endocrinol Metab. (2009) 94:3065-71. doi: 10.1210/jc.2009-0542 
44. Pagès G, Pouysségur J. Transcriptional regulation of the vascular endothelial growth factor gene-a concert of activating factors. Cardiovasc Res. (2005) 65:564-73. doi: 10.1016/j.cardiores.2004.09.032

45. Tanco VM, Ratto MH, Lazzarotto M, Adams GP. Dose-response of female llamas to ovulation-inducing factor from seminal plasma. Biol Reprod. (2011) 85:452-6. doi: 10.1095/biolreprod.111.091876

46. Silva ME, Colazo MG, Ratto MH. GnRH dose reduction decreases pituitary LH release and ovulatory response but does not affect corpus luteum (CL) development and function in llamas. Theriogenology. (2012) 77:1802-10. doi: 10.1016/j.theriogenology.2011.12.024

47. Sekar N, Garmey JC, Veldhuis JD. Mechanisms underlying the steroidogenic synergy of insulin and luteinizing hormone in porcine granulosa cells: joint amplification of pivotal sterol-regulatory genes encoding the lowdensity lipoprotein (LDL) receptor, steroidogenic acute regulatory (stAR) protein and cytochrome P450 side-chain cleavage (P450scc) enzyme. Mol Cell Endocrinol. (2000) 159:25-35. doi: 10.1016/S0303-7207(99) 00203-8

48. Sekar N, Lavoie HA, Veldhuis JD. Concerted regulation of steroidogenic acute regulatory gene expression by luteinizing hormone and insulin (or insulin- like growth factor I) in primary cultures of porcine granulosa-luteal cells. Endocrinology. (2000) 141:3983-92. doi: 10.1210/endo.141.11.7763

49. Silva M, Ulloa-Leal C, Norambuena C, Fernández A, Adams GP, Ratto $\mathrm{MH}$. Ovulation-inducing factor (OIF/NGF) from seminal plasma origin enhances Corpus Luteum function in llamas regardless the preovulatory follicle diameter. Anim Reprod Sci. (2014) 148:221-7. doi: 10.1016/j.anireprosci.2014.05.012

Conflict of Interest: The authors declare that the research was conducted in the absence of any commercial or financial relationships that could be construed as a potential conflict of interest.

Copyright (C) 2020 Valderrama, Ulloa-Leal, Silva, Goicochea, Apichela, Argañaraz, Sari, Paiva, Ratto and Ratto. This is an open-access article distributed under the terms of the Creative Commons Attribution License (CC BY). The use, distribution or reproduction in other forums is permitted, provided the original author(s) and the copyright owner(s) are credited and that the original publication in this journal is cited, in accordance with accepted academic practice. No use, distribution or reproduction is permitted which does not comply with these terms. 